\title{
Simultaneous Tympanoplasty Procedure \\ Bilateral Type as a Day Care
}

\author{
Abhishek Vijay Sahu, ${ }^{1}$ Dhrubajyoti Datta, ${ }^{1}$ Jeumon Talukdar, ${ }^{1}$ Narendranath Dutta ${ }^{1}$
}

\section{Introduction:}

\section{ABSTRACT}

Bilateral same day type I tympanoplasty scores over unilateral type I tympanoplasty in terms of convenience and conservation of resources but, it is rarely performed because of theoretical risk of postoperative sensorineural deafness.

\section{Materials and Methods}

A total of 60 patients with central perforation of tympanic membrane of both ears were included in this study. Thirty patients had undergone unilateral type I tympanoplasty and an equal number of patients were treated with bilateral type I tympanoplasty in the same sitting. The results were compared to evaluate the advantages and efficacy of single sitting bilateral type I tympanoplasty with unilateral type I tympanoplasty.

\section{$\underline{\text { Result }}$}

Perforation closure was successful in $94.6 \%$ and $93.3 \%$ ears while hearing improvement in $82.1 \%$ and $86.6 \%$ in group I (bilateral tympanoplasty) and group II (unilateral tympanoplasty) respectively. Mean hearing gain for successfully operated ears in group I (both left and right) and group II is $18.1 \mathrm{~dB}$ and $16.5 \mathrm{~dB}$. None of the patients developed iatrogenic sensorineural hearing loss.

\section{Discussion}

Bilateral perforations of the TM is a common finding and CSOM is found to be the most common cause in more than $90 \%$ of patients. The outcome of bilateral single stage tympanoplasty is sparse in the literature. Most of the reports pertain to unilateral operations with average success rates of about $60-100 \%$.

\section{Conclusion}

Single sitting bilateral type I tympanoplasty by transcanal routes is safe day care procedure with a high success rate. Keywords:

Tympanoplasty; Perichondrium; Otitis Media.

B ilateral same day type I tympanoplasty is not routinely performed by otosurgeons because of the theoretical risk of iatrogenic sensorineural hearing loss (HL) in one ear, which, in cases of conventional two-stage procedures, would change the indication for operation or the nature of the procedure to be performed on the second ear. The risk of iatrogenic $\mathrm{HL}$ in ear surgery has been reported to be $1.2-4.5 \% .^{1,2,3}$ It is however, crucial to note that these incidents with HL occurred in patients with cholesteatoma, congenital

1 - Department of ENT, Downtown Hospital, Guwahati

\section{Corresponding author:}

Dr Abhishek Vijay Sahu

email: nehabania@yahoo.in malformations or in cases in which ossiculoplasty was performed. Another disagreement against a bilateral procedure includes the use of ear canal pack with various materials.

\section{Materials and Methods:}

A total of 60 patients with central perforation of tympanic membrane of both ears were included in this study. Thirty patients had undergone unilateral type I tympanoplasty and an equal number of patients were treated with bilateral type I tympanoplasty in the same sitting. The aims and objectives of the study are to compare the results and to evaluate the advantages and efficacy of single sitting bilateral type I tympanoplasty with unilateral type 
I tympanoplasty. This is a prospective study.

A total of 60 patients with bilateral small to medium central tympanic membrane (TM) perforations, attending the ENT OPD from June 2012 to March 2016 were included in the study. They were divided into two groups by allotting them with alternate numbers, such that group I had 30 patients (60 ears) with even numbers for single sitting bilateral type I tympanoplasty and group II had 30 patients with odd numbers for unilateral type I tympanoplasty. All patients were subjected to full history taking, general and local examination, including otoscopic ear examination to ensure the diagnosis and if required diagnostic nasal endoscopy to rule out sinonasal disease which may cause eustachian tube dysfunction.

Patients with bilateral small to medium central perforation, with mild to moderate conductive HL (25$40 \mathrm{~dB}$ ) and having wide external auditory canal with no anterior overhang, where anterior margin of perforation was visualised, were included in the study. The patients had healthy middle ear mucosa without any ossicular or mastoid pathology. Nasal airway and pharyngeal opening of the Eustachian tube were assessed by diagnostic nasal endoscopy. The ears were dry for more than one month.

Patients with actively discharging ear or dry perforation for less than 1 month were excluded from the study. Large, subtotal, total, attic or marginal perforation and central perforation with ill-defined margins or margins adhesive to promontory were also not included. Patients requiring revision ear surgery or the ears with suspected ossicular pathology with air bone gap of more than $40 \mathrm{~dB}$ were not considered for this study, as also the patients having sensorineural or mixed hearing loss.

Pure tone audiogram to measure the threshold level of hearing and routine haematological investigations was done for each patient. Patients were counselled regarding the pros and con of single sitting bilateral type I tympanoplasty techniques and were admitted in the morning on the day of surgery.

Cases were operated both under local and general anaesthesia depending upon the age and preference of the patient. Anaesthesia preferred was local and premedication for these cases was given half an hour before the operation.

Patients were positioned in a supine position with their head turned to one side. The side with a larger perforation was operated first so as to exclude concomitant pathology like granulation tissue, cholesteatoma or ossicular chain defect. Operative ear was cleaned and draped. Local infiltration was given with $2 \%$ pre-prepared lignocaine and adrenaline at the site of harvesting the tragal perichondrium, postaurally, incisura terminalis and in the four quadrants of the external auditory canal (EAC). All patients intraoperatively received single dose of $3 \mathrm{rd}$ generation cephalosporin injection 1.5 gram intravenous which was continued postoperatively in oral form for a week.

For harvesting the graft, an incision was made just behind and along the free margin of the tragus for cosmesis and the tragal cartilage along with the perichondrium was harvested. Adequate perichondrium was removed from the cartilage such that its diameter was larger than of the size of perforation. The tragal cartilage was then placed back in the tragal area and incision closed with 3.0 catgut.

Transcanal approach was used for all the procedures. Under microscopic vision, the margins of the perforations were freshened and undermined to promote good capillary blood. Tympanosclerotic patch, if present, was removed. Posterior tympanomeatal incision was taken around 4 to $6 \mathrm{~mm}$ lateral to the annulus from 6 to 12 O'clock position. In cases where the anterior margins of perforation were lying anterior to the handle of malleus, the superior limb of the tympanomeatal incision was extended anteriorly and the handle of malleus was skeletonized.

The posterior tympanomeatal flap along with the annulus was elevated and middle ear was explored. After placing gelfoam in the middle ear, the tragal perichondrium graft was placed using underlay technique in all cases and under the handle of malleus whenever skeletonised. The tympanomeatal flap was then repositioned and secured with gelfoam on the lateral surface in the EAC. After the operation of one ear, EAC packs were inserted and box ear dressing was done (Fig. 1). The head was then turned over to the other side, exposing the second ear for surgery and a similar 

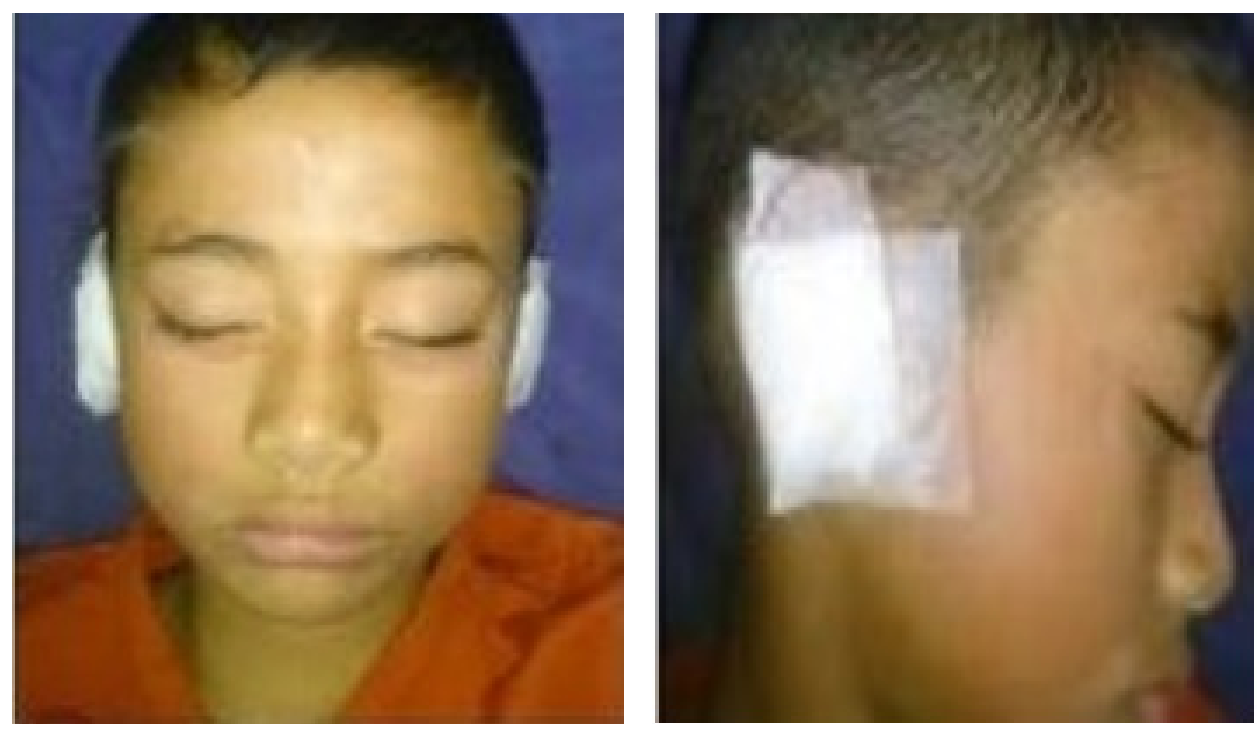

Fig.1: Anterior and lateral view of box dressing

procedure was carried out.

Patient were discharged on the same day after observation for 4 hours for cases which were done under local anaesthesia and 6 hours for cases which were done under general anaesthesia. They were instructed not to blow their nose for 1 month after surgery, to prevent water entry into their ear, to avoid catching cold and swimming. They were also instructed to avoid excessive activity or heavy lifting for 10-15 days. They were routinely kept on oral antibiotic for 1 week and antihistaminic for 3 weeks.

Box dressing and ear pack was removed at 10 days, after which antibiotic ear drops were prescribed for 2 weeks. Then, the patients were followed up on 3rd, 6th and 12 th week. On each visit, patients were evaluated for level of discomfort, success for graft uptake, sensorineural HL and complication if any. Repeat audiogram to check the hearing improvement was carried out at 12 th week.

Successful closure of the perforation was defined as an intact eardrum at 12th week postoperatively. Success in terms of hearing gain was defined as an improvement in air conduction thresholds by $10 \mathrm{~dB}$ or more in comparison with the preoperative audiogram.

\section{Results:}

The age of the patients ranged from 12 to 60 years (mean age 38 years). In group I, 28 patients fulfilled the inclusion criteria and were included in the study and 2 patients did not return for follow up at 12 week and hence was excluded from the study. Of the 56 ears operated upon, perforation closure was successful in 53 ears $(94.64 \%)$, whereas the remaining 3 ears $(5.35 \%)$ had a residual small perforation (Table I).

Table I: Effect of type I tympanoplasty on perforation closure

\begin{tabular}{|c|c|l|}
\hline $\begin{array}{c}\text { TOTAL } \\
\text { EARS }\end{array}$ & GROUP I (N=28) & GROUP II (N=30) \\
\hline $\begin{array}{c}\text { Successful } \\
\text { closure }\end{array}$ & $53(94.64 \%)$ & $28(93.33 \%)$ \\
\hline $\begin{array}{c}\text { Graft } \\
\text { failure }\end{array}$ & $3(5.35 \%)$ & $2(6.66 \%)$ \\
\hline
\end{tabular}

46 ears $(82.1 \%)$ gained hearing, whereas in the remaining 10 ears (17.8\%) no hearing was gained, including 3 ears with residual perforations. In group II, successful perforation closure was seen in 28 ears (93.33\%) and hearing gain in 26 ears $(86.66 \%)$ (Table II). Worsening of hearing did not occur in any operated ear in this study.

Pre and post-operative hearing threshold and mean hearing gain for successfully operated ears in group I 
Table II: Effect of type I tympanoplasty on hearing gain

\begin{tabular}{|c|c|c|}
\hline $\begin{array}{c}\text { TOTAL } \\
\text { EARS }\end{array}$ & GROUP I $(\mathrm{N}=28)$ & GROUP II $(\mathrm{N}=30)$ \\
\hline $\begin{array}{c}\text { Hearing } \\
\text { gain }\end{array}$ & $46(82.1 \%)$ & $26(86.66 \%)$ \\
\hline $\begin{array}{c}\text { No hearing } \\
\text { gain }\end{array}$ & $10(17.8 \%)$ & $4(13.33 \%)$ \\
\hline
\end{tabular}

and group II is listed in Table III. Mean hearing gain for successfully operated ears in group I (both left and right) and group $\mathrm{II}$ is $18.1 \mathrm{~dB}$ and $16.5 \mathrm{~dB}$. To compare hearing gain in the two group independent sample ttest was applied (Table IV). There was no statistically significant difference in hearing gain in the two groups. ( $p=0.231$ ) but the gain in hearing in the two groups were comparable.

In group I the air bone gap was less than $10 \mathrm{~dB}$ in 46 and less than $20 \mathrm{~dB}$ in 51 operated ears where as in group II it was less than $10 \mathrm{~dB}$ in 19 and less than $20 \mathrm{~dB}$ in 26 operated ears (Table V).

In terms of success rate, it is interesting to note that all patients in group I had TM perforation closure and hearing gain at least in one ear. 25 of 28 patients $(89.28$ $\%$ ) achieved bilateral graft uptake and 23 of 28 patients $(82.14 \%)$ had bilateral hearing improvement.

It was very encouraging that 27 patients in group I $(96.42 \%)$ were not annoyed by the bilateral ear canal gauze packing and box dressing and only 1 patient $(3.57 \%)$ was intolerant to the bilateral dressing in the
Table III: Pre and postoperative hearing threshold

\begin{tabular}{|c|c|c|}
\hline HEARING & GROUP I $(\mathrm{N}=\mathbf{2 8})$ & GROUP II $(\mathrm{N}=\mathbf{3 0})$ \\
\hline $\begin{array}{c}\text { Mean } \\
\text { preoperative } \\
\text { hearing } \\
\text { threshold }\end{array}$ & $32.07 \mathrm{~dB}$ & $30 \mathrm{~dB}$ \\
\hline $\begin{array}{c}\text { Mean } \\
\text { postoperative }\end{array}$ & $13.96 \mathrm{~dB}$ & $13.5 \mathrm{~dB}$ \\
\hline $\begin{array}{c}\text { Mean hearing } \\
\text { gain }\end{array}$ & $18.1 \mathrm{~dB}$ & $16.5 \mathrm{~dB}$ \\
\hline
\end{tabular}

early postoperative period, as immediate postoperative hearing was compromised. During postoperative follow up no retraction pocket, no lateralization or medial displacement of the graft was observed in both the groups. Operative blood loss was minimal and postoperative pain was tolerable in all patients.

\section{Discussion:}

Perforation of TM is quite common among patients seen at the Otorhinolaryngology clinic. Bilateral perforations of the TM is a common finding as it represents about $39.4 \%$ of perforated TM, and CSOM was found to be the most common cause of TM perforation in more than $90 \%$ of patients. ${ }^{4}$

It has been found that the effect of enhanced ratio of the surface area of the TM and that of the oval window increases the sound pressure by about $27 \mathrm{~dB}$, whereas

Table IV: Statistical analysis using independent sample t- test

\begin{tabular}{|c|c|c|c|c|c|c|}
\hline & & \multicolumn{2}{|c|}{$\begin{array}{c}\text { LEVENE'S TEST FOR } \\
\text { EQUALITY OF VARIANCES }\end{array}$} & \multicolumn{3}{|c|}{ T-TEST FOR EQUALITY OF MEANS } \\
\hline & & $\mathbf{F}$ & Sig. & $\mathbf{t}$ & df & Sig. (2-tailed) \\
\hline \multirow{2}{*}{$\mathbf{G}$} & Equal variances & 1.332 & 0.253 & 1.21 & 56 & 0.228 \\
\hline & Assumed & & & 8 & & \\
\hline \multirow{2}{*}{$\mathbf{H}$} & Equal variances & & & 1.21 & 53.5 & 0.231 \\
\hline & Assumed & & & 2 & 63 & \\
\hline
\end{tabular}


Table V: Air bone gap closure

\begin{tabular}{|c|c|c|}
\hline $\begin{array}{c}\text { ABG } \\
\text { CLOSURE }\end{array}$ & GROUP I (N=28) & GROUP II (N=30) \\
\hline $\begin{array}{c}\text { ABG Less } \\
\text { than } 10 \mathrm{~dB}\end{array}$ & $46(82.14 \%)$ & $19(63.33 \%)$ \\
\hline $\begin{array}{c}\text { ABG less than } \\
20 \mathrm{~dB}\end{array}$ & $51(91.07 \%)$ & $26(86.66 \%)$ \\
\hline
\end{tabular}

the lever action of ossicles contributes only about 3 $\mathrm{dB} .{ }^{5} \mathrm{TM}$ perforation reduces the surface area of the membrane available for sound pressure transmission and allows sound to pass directly into the middle ear. ${ }^{6}$ The objectives of tympanoplasty are obtaining an intact TM and a dry middle ear and audiometric improvement. ${ }^{7}$

In this study in group I on simultaneous bilateral type I tympanoplasty, the graft take rate at 12 week postoperatively is $94.64 \%$, which is within the average reported success rate of previous studies on bilateral ear surgeries as shown in the Table IV. The study has an additional advantage that all cases were done by transcanal approach using tragal perichondrium as the graft material thereby minimizing variations in the results. The failure rate of TM perforation repair in this

Table VI: Comparison of results of various studies on bilateral tympanoplasty

\begin{tabular}{|c|c|c|c|c|c|c|c|}
\hline SR. NO. & STUDY & PROCEDURE & MATERIAL & APPROACH & $\begin{array}{c}\text { NO OF } \\
\text { EARS }\end{array}$ & $\begin{array}{c}\text { SUCCESS } \\
\text { RATE } \%\end{array}$ & $\begin{array}{l}\text { HEARING } \\
\text { GAIN }\end{array}$ \\
\hline 1 & $\begin{array}{c}\text { Mitchell et } \\
\text { al. }^{8}\end{array}$ & Myringoplasty & Fat graft & $\begin{array}{c}\text { Transcanal } \\
\text { without } \\
\text { tympano- } \\
\text { meatal flap }\end{array}$ & 56 & 91 & - \\
\hline 2 & $\begin{array}{c}\text { Katsura et } \\
\text { al. }{ }^{9}\end{array}$ & Myringoplasty & - & - & 17 & 91 & 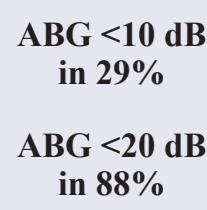 \\
\hline 3 & $\begin{array}{c}\text { Caye - } \\
\text { Thomasen }^{10}\end{array}$ & Myringoplasty & $\begin{array}{c}\text { Temporalis } \\
\text { fascia }(56 \%), \\
\text { tragalperi- } \\
\text { chondrium } \\
(38 \%), \\
\text { cartilage }\end{array}$ & $\begin{array}{c}\text { Transcanal } \\
83 \%\end{array}$ & 52 & 94 & $\begin{array}{c}\mathrm{ABG}<10 \mathrm{~dB} \\
\text { in } 92 \% \\
\mathrm{ABG}<20 \mathrm{~dB} \\
\text { in } 100 \%\end{array}$ \\
\hline 4 & Hydr et al. ${ }^{11}$ & - & - & - & 100 & 84 & $\begin{array}{c}\text { Average } \\
\text { ABG }<15 \text { dB }\end{array}$ \\
\hline 5 & $\begin{array}{l}\text { Homoe et } \\
\text { al. }^{12}\end{array}$ & - & - & - & 34 & 65 & $\begin{array}{c}\text { Average gain } \\
18 \mathrm{~dB} \text { in } \\
\text { right, 13dB } \\
\text { in left }\end{array}$ \\
\hline 6 & $\begin{array}{l}\text { Mane et } \\
\text { al. }^{13}\end{array}$ & $\begin{array}{c}\text { Type I } \\
\text { tympanoplasty }\end{array}$ & $\begin{array}{l}20 \text { fascia lata, } \\
8 \text { temoralis } \\
\text { fascia }\end{array}$ & $\begin{array}{l}\text { Endomeatal } \\
17 \text {, endaural } \\
6 \text {, postaural } 5\end{array}$ & 28 & 96 & $\begin{array}{c}\mathrm{ABG}<10 \mathrm{~dB} \\
\text { in } 92 \% \\
\mathrm{ABG}<20 \mathrm{~dB} \\
\text { in } 100 \%\end{array}$ \\
\hline
\end{tabular}




\begin{tabular}{|c|c|c|c|c|c|c|c|}
\hline 7 & $\begin{array}{l}\text { Raghu- } \\
\text { wanshi }^{14}\end{array}$ & $\begin{array}{c}\text { Type I } \\
\text { tympanoplasty }\end{array}$ & $\begin{array}{l}59 \text { temporalis } \\
\text { fascia ,5tragal } \\
\text { perichondrium }\end{array}$ & $\begin{array}{c}\text { Postaural 27, } \\
\text { endaural 22, } \\
\text { endomeatal } \\
15\end{array}$ & 64 & 93.7 & $\begin{array}{c}\mathrm{ABG}<10 \mathrm{~dB} \\
\text { in } 70 \% \\
\mathrm{ABG}<20 \mathrm{~dB} \\
\text { in } 91.6 \%\end{array}$ \\
\hline 8 & $\mathbf{R a i}^{15}$ & $\begin{array}{c}\text { Type I } \\
\text { tympanoplasty }\end{array}$ & $\begin{array}{l}\text { Temporalis } \\
\text { fascia }\end{array}$ & Postaural & 60 & 93 & $\begin{array}{l}A B G<20 \\
d B \text { in } 94 \%\end{array}$ \\
\hline 9 & Sharma ${ }^{16}$ & Myringoplasty & $\begin{array}{l}\text { Temporalis } \\
\text { fascia }\end{array}$ & $\begin{array}{c}\text { Mini } \\
\text { endaural and } \\
\text { permeatal }\end{array}$ & 50 & 90 & - \\
\hline 10 & $\begin{array}{l}\text { Present } \\
\text { study }\end{array}$ & $\begin{array}{c}\text { Type I } \\
\text { tympanoplasty }\end{array}$ & $\begin{array}{l}\text { Tragalperi- } \\
\text { chondrium }\end{array}$ & Transcanal & 56 & 94.64 & $\begin{array}{c}\mathrm{ABG}<10 \mathrm{~dB} \\
\text { in } 66.07 \% \\
\text { ABG }<20 \mathrm{~dB} \\
\text { in } 83.92 \%\end{array}$ \\
\hline
\end{tabular}

study is $5.35 \%$. There was no difference in the outcome among male and female patients.

The outcome of bilateral single stage tympanoplasty is sparse in the literature. Most of the reports pertain to unilateral operations with average success rates of about $60-100 \%{ }^{17,18}$ The take rate of $96 \%$ is in agreement with international standards of unilateral tympanoplasty type I. ${ }^{19}$ Glasscock at el. had a graft take up rate of $93 \%$ in a sample of 1556 patient using autogenous and homograft temporalis fascia by underlay technique. ${ }^{20}$ In the present study the graft uptake rate of $93.33 \%$ in the group II is also similar to the above studies.

In considering bilateral surgery for TM perforations, only dry ears with no suspicion of additional pathology should be included because granulation tissue or a need to perform ossiculoplasty will increase the risk fora iatrogenic sensorineural HL during the operation. 1

In the study, the air bone gap for bilateral single sitting type I tympanoplasty was less than $10 \mathrm{~dB}$ in 46 operated ears $(82.14 \%)$ and less than $20 \mathrm{~dB}$ in 51 operated ears (91.07\%) which is also within the average reported success rate of the previous studies in the table V. No worsening of bone conduction threshold was detected in any ear in our study, which is concordant with the findings of Caye-Thomasenet al. ${ }^{10}$ and Karkanevatos et al. $^{21}$

\section{Conclusion}

Single sitting bilateral ( type I ) tympanoplasty by transcanal routes is safe day care procedure with a high success rate. It can be performed in most patients without apprehension of sensorineural HL with good results comparable to unilateral type I tympanoplasty. It reduces the cost of treatment, allows single hospital admission, decreases the frequency of exposure to anaesthesia and leaves the patient satisfied. It avoids the need for a second surgery thereby reducing the number of days of absence from school and work, and also reduces the burden on the healthcare system. The hearing impairment during postoperative period with ear canal pack is minimal and radially acceptable by the patients. 


\section{References:}

1. Palva T, Karja J, Palva A. High-tone sensorineural losses following chronic ear surgery. Arch Otolaryngology 1973; 98:176-8

2. Smyth GD. Sensorineural hearing loss in chronic ear surgery. Annals of Otorhinolaryngology 1977; 86:1-6

3. Tos M, Lau T, Plate S. Sensorineural hearing loss following chronic ear surgery. Annals of Otorhinolaryngology 1984; 93:403-9

4. Olowookere SA, Ibekwe TS, Adeosun AA. Pattern of tympanic membrane perforation in Ibadan: a prospective study. Annals of Ibadan Postgraduate Medicine 2008; 6:843-53

5. Voss SE, Rosowski JJ, Merchant SN, Peake WT. Non-ossicular signal transmission in human middle ears: experimental assessment of the 'acousticroute' with perforated tympanic membranes. Journal Acoust Soc Am. 2007; 122:2135-53

6. Maharjan M, Kafle P, Bista M, Shrestha S, Toran KC. Observation of hearing loss in patients with chronic suppurative otitis media tubotympanic type. Kathmandu University Medical Journal 2009; 7:397-401

7. Kumar N, Madkikar NN, Kishve S, Chilke D, Shinde KJ. Using middle ear risk index and ET function as parameters for predicting the outcome of tympanoplasty. Indian Journal Otolaryngology Head Neck Surgery 2012; 64:13-6

8. Mitchell RB, Pereira KD, Younis RT, Lazar RH. Bilateral fat graft myringoplasty in children. Ear Nose Throat Journal 1996; 75:652-6

9. Katsura H, Sakagami M, Tsuji K et al. Reevaluation of bilateral same-day surgery for bilateral perforated chronic otitis media. Otology and Neurotology 2005 26:842-5

10. Caye-Thomasen P, Nielsen TR, Tos M. Bilateral myringoplasty in chronic otitis media. Laryngoscope 2007; 117:903-6

11. Hydr AS, Ashfaq M. Single stage bilateral myringoplasty.
Pakistan Journal of Otolaryngology 2007; 23:66-7

12. Homoe P, Sorensen HC, Tos M. Mobile, one stage, bilateral ear surgery for chronic otitis media patients in remote areas. Journal of Laryngology and Otology 2009; 123:1108-13

13. Mane R, Patil B, Mohite A, Varute VV. Bilateral type 1 tympanoplasty in chronic otitis media. Indian Journal of Otolaryngology HeadNeck Surgery 2013; 65(4):293-7

14. Raghuwanshi SK, Asati DP. Outcome of single-sitting bilateral type I tympanoplasty in Indian patient. Indian Journal of Otolaryngology Head Neck Surgery2013; 65(Suppl. 3):S622-6

15. Rai AK, Singh GB, Sahu R, Singh S, Arora R. Evaluation of simultaneously bilateral same day tympanoplasty type I in chronic suppurative otitis media. Auris Nasus Larynx. 2014 Apr; 41(2):148-52

16. Sharma RC, Saroch M. Our experience with single sitting bilateral myringoplasty. Indian Journal of Otology 2013; 19(2): 59-61

17. Fukuchi I, Cerchiari DP, Garcia E, Rezende CE, Rapoport PB. Tympanoplasty: surgical results and a comparison of thefactors that may interfere in their success. Brazilian Journal of Otorhinolaryngology 2006; 72:267-71

18. Singh GB, Sidhu TS, Sharma A, Singh N. Tympanoplasty type I in children - an evaluative study. International Journal Pediatric Otorhinolaryngology 2005; 69:1071-6

19. Tos M. Manual of middle ear surgery, Thieme, New York 1993; Vol 1

20. Glasscock ME III, Jackson CG, Nissen AJ, Schwaber MK. Postauricular undersurface tympanic membrane grafting: A follow-up report. Laryngoscope 1982; 92(7 Pt 1): 718-27

21. Karkanevatos A, De S, Srinivasan VR, Roland NJ, Lesser THJ. Day-case myringoplasty: five years' experience. Journal of Laryngology and Otology 2003; 117:763-5. 